\title{
Serotonin Receptor Activation Inhibits Sodium Current and Dendritic Excitability in Prefrontal Cortex via a Protein Kinase C-Dependent Mechanism
}

\author{
David B. Carr, ${ }^{1,3}$ Donald C. Cooper, ${ }^{2,3}$ Sasha L. Ulrich, ${ }^{1,3}$ Nelson Spruston,, ${ }^{2,3}$ and D. James Surmeier ${ }^{1,3}$ \\ ${ }^{1}$ Department of Physiology, ${ }^{2}$ Department of Neurobiology and Physiology, and 3/nstitute for Neuroscience, Northwestern \\ University, Chicago, Illinois 60611
}

The serotonin (5-HT) innervation of the prefrontal cortex (PFC) exerts a powerful modulatory influence on neuronal activity in this cortical region, although the mechanisms through which 5-HT modulates cellular activity are unclear. Voltage-dependent $\mathrm{Na}^{+}$channels are one potential target of 5-HT receptor signaling that have wide-ranging effects on activity. Molecular and electrophysiological studies were used to test this potential linkage. Single cell RT-PCR profiling revealed that the vast majority of pyramidal neurons expressed detectable levels of $5-\mathrm{HT}_{2 \mathrm{a}}$ and/or $5-\mathrm{HT}_{2 \mathrm{c}}$ receptor mRNA with half of the cells expressing both mRNAs. Whole-cell voltage-clamp recordings of dissociated pyramidal neurons showed that $5-\mathrm{HT}_{2 \mathrm{a} / \mathrm{c}}$ receptor activation reduced rapidly inactivating $\mathrm{Na}^{+}$currents by reducing maximal current amplitude and shifting fast inactiva-

The prefrontal cortex (PFC) has long been implicated in the neuropathology of schizophrenia, particularly in the manifestation of negative symptoms, such as decreased motivation, social withdrawal, and poor judgment (Weinberger, 1988). The search for the pathophysiology underlying schizophrenia originally focused on dopamine (DA) signaling. This choice was predicated primarily on the observation that the clinical efficacy of most typical antipsychotic drugs is strongly correlated with their affinity for the $\mathrm{D}_{2}$ DA receptor class (Seeman, 1992). However, the exclusive role of DA in schizophrenia has been called into question by the clinical inefficacy of $\mathrm{a}_{4}$ receptor selective antagonist (Bristow et al., 1997) and the efficacy of atypical anti-psychotic drugs, such as clozapine and risperidone, which have a high affinity for serotonin 5-HT 2 receptors (Meltzer, 1999).

Although implicated by clinical observation, relatively little is known about how $5-\mathrm{HT}_{2}$ receptor stimulation shapes the activity of PFC pyramidal neurons. Previous studies have yielded conflicting results. In vivo extracellular recording studies in rodents, using either raphe stimulation (Mantz et al., 1990) or iontophoretic drug application (Ashby et al., 1989), have suggested that 5- $\mathrm{HT}_{2}$ receptors decrease spontaneous discharge in PFC neurons. In contrast, in vitro slice recordings have reported that $5-\mathrm{HT}_{2}$ receptors increase the excitability of PFC neurons (Araneda and An-

Received Dec. 27, 2001; revised May 7, 2002; accepted May 10, 2002.

This work is supported by United States Public Health Service Grants MH64322 (D.B.C.), NS35180 (N.S.), and MH62070 (D.J.S.). We thank the laboratory of Dr. Heidi Hamm for purifying the $\mathrm{G}_{\mathrm{q}}$ peptide.

Correspondence should be addressed to D. James Surmeier, Department of Physiology/NUIN, 320 East Superior Street, Searle 5-447, Northwestern University Medical School, Chicago, IL 60611. E-mail: j-surmeier@northwestern.edu.

Copyright (C) 2002 Society for Neuroscience 0270-6474/02/226846-10\$15.00/0 tion voltage dependence. These effects were mediated by $\mathrm{G}_{\mathrm{q}}$ activation of phospholipase $\mathrm{C}$, leading to activation of protein kinase $\mathrm{C}(\mathrm{PKC}) .5-\mathrm{HT}_{2 \mathrm{a} / \mathrm{c}}$ receptor stimulation also reduced the amplitude of persistent $\mathrm{Na}^{+}$current without altering its activation voltage dependence. This modulation was also mediated by PKC. Although 5- $\mathrm{HT}_{2 \mathrm{a}, \mathrm{c}}$ receptor activation did not affect somatic action potentials of layer $\mathrm{V}$ pyramidal neurons in PFC slices, it did reduce the amplitude of action potentials backpropagating into the apical dendrite. These findings show that $5-\mathrm{HT}_{2 \mathrm{a}, \mathrm{c}}$ receptor activation reduces dendritic excitability and may negatively modulate activity-dependent dendritic synaptic plasticity.

Key words: sodium channel; serotonin; cerebral cortex; scRTPCR; neuromodulation; voltage-clamp

drade, 1991). 5- $\mathrm{HT}_{2}$ receptor stimulation has also been reported to enhance spontaneous glutamatergic EPSCs in layer V pyramidal neurons (Aghajanian and Marek, 1997), an effect that was attributed in part to an enhancement of voltage-dependent $\mathrm{Na}^{+}$ currents, possibly as a consequence of $5-\mathrm{HT}_{2}$ receptor activation of protein kinase C (PKC) (Astman et al., 1998; Franceschetti et al., 2000). Although providing important phenomenological insights, these studies have all relied on preparations in which it is impossible to separate direct from indirect neuromodulatory effects and where it is difficult to draw strong inferences about the modulation of individual voltage-dependent conductances because transmembrane potential cannot be controlled adequately.

To overcome these obstacles, we performed voltage-clamp experiments on acutely isolated, PFC pyramidal neurons. This preparation eliminates indirect neuromodulatory effects and provides excellent control of transmembrane voltage. As a first step toward unraveling the role of 5-HT in control PFC excitability, we asked whether postsynaptic $5-\mathrm{HT}_{2}$ receptors were functionally coupled to voltage-dependent $\mathrm{Na}^{+}$channels. There is a growing recognition that these channels regulate not only somatic spike generation but also dendritic integration of synaptic input (Schwindt and Crill, 1995; Stuart and Sakmann, 1995; Lipowsky et al., 1996; Gonzalez-Burgos and Barrionuevo, 2001), making them an important potential target of neuromodulation. Our studies demonstrate that $5-\mathrm{HT}_{2}$ receptor activation reduces both rapidly inactivating and persistent $\mathrm{Na}^{+}$channel currents through a PKC-dependent mechanism. Moreover, somatic and dendritic current-clamp recordings from pyramidal neurons in PFC slices reveal that this reduction attenuates action potential backpropagation through the apical dendrite, suggesting that dendritic $5-\mathrm{HT}_{2}$ receptors are capable of reducing dendritic excitability. 


\section{MATERIALS AND METHODS}

Acute dissociation of PFC neurons. Three- to five-week old C57/BL6 mice were anesthetized with isofluorane and decapitated. The brain was quickly removed, blocked, and sectioned $(350 \mu \mathrm{m})$ in an ice-cold sucrose solution containing (in $\mathrm{mm}$ ): 250 sucrose, 11 glucose, 15 HEPES, 4 $\mathrm{MgSO}_{4}, 1 \mathrm{NaH}_{2} \mathrm{PO}_{4}, 2.5 \mathrm{KCl}, 1$ kynurenic acid, $0.1 \mathrm{~N}$-nitro-L-arginine, and 0.005 glutathione, $\mathrm{pH} 7.4,300-305 \mathrm{mOsm} / 1$. Unless noted otherwise, all chemicals were obtained from Sigma (St. Louis, MO). Coronal slices were collected in a low-Ca ${ }^{2+}$ buffer containing (in mM): $140 \mathrm{Na}-$ isothionate, 23 glucose, 15 HEPES, $2 \mathrm{KCl}, 4 \mathrm{MgCl}_{2}, 0.2 \mathrm{CaCl}_{2}, 1$ kynurenic acid, $0.1 \mathrm{~N}$-nitro-L-arginine, and 0.005 glutathione, $\mathrm{pH} 7.4$, 300-305 $\mathrm{mOsm} / 1$ before being incubated for $1-5 \mathrm{hr}$ in sodium bicarbonate buffered Earle's balanced salts solution (EBSS) bubbled with $95 \% \mathrm{O}_{2}$ and $5 \% \mathrm{CO}_{2}$. EBSS also contained (in $\mathrm{mm}$ ): 23 glucose, 1 kynurenic acid, $0.1 \mathrm{~N}$-nitro-L-arginine, and 0.005 glutathione. Individual slices were transferred to the low-Ca ${ }^{2+}$ buffer and the PFC (prelimbic and infralimbic cortices; Franklin and Paxinos, 1997) dissected and incubated at $35^{\circ} \mathrm{C}$ for $25 \mathrm{~min}$ in oxygenated Hank's buffered salts solution containing (in mM): $11 \mathrm{HEPES}, 4 \mathrm{MgCl}_{2}, 1 \mathrm{CaCl}_{2}, 1$ pyruvic acid, 1 kynurenic acid, $0.1 \mathrm{~N}$-nitro arginine, 0.005 glutathione, and $1 \mathrm{mg} / \mathrm{ml}$ protease XIV, $\mathrm{pH}$ $7.4,300-305 \mathrm{mOsm} / 1$. After this enzyme incubation, the tissue was transferred to the low-Ca ${ }^{2+}$ HEPES-buffered saline, rinsed, and mechanically dissociated using fire-polished Pasteur pipettes. The resulting cell suspension was plated onto a $35 \mathrm{~mm}$ Petri dish mounted on an inverted microscope. During the course of the experiment, nonrecorded cells were constantly perfused with a background solution containing (in mM): $140 \mathrm{NaCl}, 23$ glucose, 15 HEPES, $2 \mathrm{KCl}, 2 \mathrm{MgCl}_{2}$, and $1 \mathrm{CaCl}_{2}$, $\mathrm{pH} 7.4,300-305 \mathrm{mOsm} / 1$. All recordings were performed at room temperature.

Whole-cell recording methods. Whole-cell recordings were performed using electrodes pulled from Corning (Corning, NY) 7052 glass, coated with R-6101 (Corning), and fire polished immediately before use. Electrodes were typically $1.5-2.5 \mathrm{M} \Omega$ in the bath. Recordings were obtained via an Axopatch 200A amplifier (Axon Instruments, Foster City, CA) interfaced to a Macintosh computer running Pulse software (Heka, Lambrecht, Germany). After the gigaohm seal was formed and the cell membrane was ruptured, series resistance was compensated (75-80\%) and frequently monitored. The intracellular recording solution contained (in mM): $70 \mathrm{~N}$-methyl-D-glucamine, $20 \mathrm{HEPES}, 50 \mathrm{Cs}_{2} \mathrm{SO}_{4}, 2 \mathrm{MgCl}_{2}, 0.5$ $\mathrm{Na}_{2} \mathrm{SO}_{4}, 12$ phosphocreatine, $2 \mathrm{Mg}$-ATP, $0.7 \mathrm{Na}_{2}$-GTP, and 0.1 leupeptin, $\mathrm{pH} 7.25$, with $\mathrm{H}_{2} \mathrm{SO}_{4}, 265-270 \mathrm{mOsm} / 1$. During recording, cells were bathed in extracellular solutions applied via a gravity-fed capillary perfusion array positioned several hundred micrometers away from the cell under study. Bathing solutions were changed by adjusting the position of the array using a DC motor (Newport, Irvine, CA). Solution changes were complete within $<1 \mathrm{sec}$. For recording rapidly inactivating $\mathrm{Na}^{+}$ currents, the external solution contained (in mM): $10 \mathrm{NaCl}, 110$ tetraethylammonium (TEA) chloride, $10 \mathrm{HEPES}, 10 \mathrm{CsCl}, 0.3 \mathrm{CdCl}_{2}, 1$ $\mathrm{MgCl}_{2}$, and $2 \mathrm{BaCl}_{2}, \mathrm{pH} \mathrm{7.4,300-305} \mathrm{mOsm/l.} \mathrm{For} \mathrm{recording} \mathrm{persistent}$ $\mathrm{Na}^{+}$currents, the external solution contained (in mM): $115 \mathrm{NaCl}, 45$ TEA chloride, 10 HEPES, $0.3 \mathrm{CdCl}_{2}, 1 \mathrm{MgCl}_{2}$, and $2 \mathrm{BaCl}_{2}, \mathrm{pH} 7.4$, $300-305 \mathrm{mOsm} / 1$. The liquid junction potential $(<1 \mathrm{mV})$ was not compensated for.

To ensure adequate voltage control, several steps were taken. Only cells with relatively short $(25-50 \mu \mathrm{m})$ processes were selected for recording; after entering whole-cell mode, often the processes retracted, making cells nearly spherical. In experiments designed to examine rapidly inactivating currents, the external $\mathrm{Na}^{+}$concentration was lowered to 10 $\mathrm{mM}$, and internal $\mathrm{Na}^{+}$was elevated; this kept currents relatively small and minimized any residual series resistance errors. In each cell, current activation plots were generated, and any evidence of loss of voltage control (discontinuities in the current-voltage relationship that would yield slope factors $<5 \mathrm{mV}$ ) resulted in the cell being discarded. Also, variation in the activation kinetics of test pulse currents evoked in inactivation protocols or during the application of a modulator was taken for evidence of bad space clamp. In several experiments, reversal potentials were examined. These invariably fell within a few millivolts of the prediction based on the Nernst equation; suggesting that the transmembrane voltage was adequately controlled. In the ramp experiments where external $\mathrm{Na}^{+}$was near physiological levels, discontinuities in the rising phase of the currents were taken as evidence of bad control; in the worst case, this was manifested as spiking. Where there was ambiguity, the $\mathrm{Na}^{+}$ current driving force was reduced, and the experiments were repeated.

Dendritic recording methods. Slices from the medial PFC were prepared from 35-to 42-d-old male Wistar rats. Rats were anesthetized with halothane and perfused with ice-cold artificial CSF (ACSF) containing (in $\mathrm{mM}$ ): $125 \mathrm{NaCl}, 25$ glucose, $25 \mathrm{NaHCO}_{3}, 2.5 \mathrm{KCl}, 1.25 \mathrm{NaH}_{2} \mathrm{PO}_{4}, 2$ $\mathrm{CaCl}_{2}$ and $1 \mathrm{MgCl}_{2}$, pH 7.4 (bubbled with $95 \% \mathrm{O}_{2}$ and $5 \% \mathrm{CO}_{2}$ ). The brain was quickly removed, and a blocking cut was performed, which was performed to preserve the medial PFC (mPFC) layer V apical dendrites. The blocking cut was made at a $45^{\circ}$ angle between the coronal and sagittal planes (medial-rostral, lateral-caudal) and a $45^{\circ}$ angle between the coronal and horizontal planes (dorsal-caudal, ventral-rostral). Slices $(300 \mu \mathrm{m})$ were incubated for 20-30 $\mathrm{min}$ in a chamber containing warm $\left(34-35^{\circ} \mathrm{C}\right) \mathrm{ACSF}$, and then held at room temperature until use. Individual slices were transferred to a chamber on a fixed stage of a Zeiss (Oberkochen, Germany) Axioscop equipped with infrared DIC optics. Layer $\mathrm{V}$ mPFC somata and dendrites were visually identified using a Dage-MTI (Michigan City, IN) tube camera. All recordings were performed during continuous perfusion with $\mathrm{ACSF}$ at $33-36^{\circ} \mathrm{C}$. Patch-clamp electrodes were fabricated from thick-walled borosilicate glass with resistances of 3-6 $\mathrm{M} \Omega$ for somatic recordings and 6-10 $\mathrm{M} \Omega$ for dendritic recordings. The internal solution consisted of (in mM): $115 \mathrm{~K}$-gluconate, $20 \mathrm{KCl}, 10 \mathrm{Na}_{2}$-phosphocreatine, $10 \mathrm{HEPES}, 2 \mathrm{EGTA}, 2 \mathrm{Mg}$-ATP, and 0.3 Na-GTP, $\mathrm{pH} 7.3$, and $0.1 \%$ biocytin for subsequent morphological identification. Data were collected using BVC-700 amplifiers (Dagan, Minneapolis, MN) and stored on a Macintosh computer using an ITC-16 analog-to-digital interface using custom macros running under Igor Pro 4.0 (WaveMetrics, Lake Oswego, OR). Voltage was filtered at $5 \mathrm{kHz}$ and digitized at $20 \mathrm{kHz}$.

Pharmacology. Drugs were dissolved as stock solutions in either water or DMSO. 5-HT stock solutions were dissolved in $0.1 \%$ sodium metabisulfite to prevent oxidation. When drugs were dissolved in DMSO or metabisulfite, equivalent amounts were added to all internal or external solutions as controls. Calphostin C, U-73122, U-73343, and 1-oleoyl-2acetyl-sn-glycerol (OAG) were obtained from Calbiochem (San Diego, CA). ( \pm )-2,5-dimethoxy-4-iodoamphetamine hydrochloride (DOI) and spiperone were obtained from Sigma. BAPTA was obtained from Molecular Probes, (Eugene, OR). The $\mathrm{G}_{\mathrm{q}}$ binding protein designed to mimic the $\mathrm{C}$ terminus of the $\mathrm{G}_{\mathrm{q}} \alpha$ subunit was synthesized by PeptidoGenic Research (Livermore, CA). The peptide sequence was Ac-LQLNLKEYNLV-OH.

Data analysis. Data were plotted and analyzed with IgorPro. Normalized $\left(g / g_{\max }\right)$ conductance-voltage and inactivation-voltage curves were fit with a Boltzmann function of the form: $g(V)=1 /\{1+\exp [(V-$ $\left.\left.\left.V_{1 / 2}\right) / k\right]\right\}$, where $V_{1 / 2}$ is the half-activation or inactivation voltage, and $k$ is the slope factor. Driving force was estimated from the Nernst equation. In experiments using low external $\mathrm{Na}^{+}$concentrations, measured reversal potentials were within a few millivolts of the predicted values. Doseresponse curves were fit with a Langmuir isotherm of the form: $I=$ $\left\{I_{\text {sat }} /\left(1+[\mathrm{A}] / \mathrm{EC}_{50}\right)^{n}+I_{\mathrm{r}}\right\}$, where $I_{\text {sat }}$ is the fraction of current blocked at saturating agonist concentrations, $I_{\mathrm{r}}$ is the fraction of current resistant to block, $[\mathrm{A}]$ is the concentration of agonist, and $\mathrm{EC}_{50}$ is the concentration of agonist producing a block equal to $50 \%$ of $I_{\text {sat }}$. Sodium currents were fit using a modified Hodgkin-Huxley equation (Hille, 1992) of the form: $I_{\mathrm{Na}}=g_{\mathrm{Na}(\max )} m^{3} h\left(V_{\mathrm{m}}-E_{\mathrm{Na}}\right)+I_{\mathrm{Na}(\mathrm{p})}$, where $I_{\mathrm{Na}(\mathrm{p})}$ is the persistent $\mathrm{Na}^{+}$current, and the inactivation parameter $h$ contains both a fast and slow time constant whose respective contributions to $h$ determined by the fraction: $\quad\left[h_{\infty}=\alpha * \exp \left(-\left(t-t_{0}\right) / \tau_{\text {fast }}\right)+(1-\alpha)^{*} \exp (-(t-\right.$ $\left.\left.\left.t_{0}\right) / \tau_{\text {slow }}\right)\right]$. Statistical analyses were performed using Systat (SPSS, Chicago, IL). Sample statistics are given as mean \pm SE for samples $\geq 10$ and median (intraquartile range) for smaller samples. In data presented as box plots, the central line represents the median, the edges of the box represents the intraquatriles, and the "whisker lines" show the extent of the overall distribution, excluding outliers (points $>1.5 \times$ intraquatrile range) that are shown as circles.

Single-cell RT-PCR. Individual PFC neurons were aspirated into sterile glass micropipettes containing diethylpyrocarbonate-treated water and $1.5 \mathrm{U} / \mu \mathrm{l}$ SUPERase-In (Ambion, Austin, TX). The contents of the pipette were transferred to thin-walled PCR tubes containing dNTPs (1 $\mu \mathrm{l}, 10 \mathrm{~mm})$, BSA $(0.7 \mu \mathrm{l}, 143 \mu \mathrm{g} / \mu \mathrm{l})$, random hexamers $(2.6 \mu \mathrm{l}, 50 \mathrm{ng} / \mu \mathrm{l})$, and Superase-In $(0.7 \mu \mathrm{l}, 40 \mathrm{U} / \mu \mathrm{l})$. All reverse transcriptase (RT) reagents were obtained from Invitrogen (Gaithersburg, MD). This mixture was heated to $65^{\circ} \mathrm{C}$ for $5 \mathrm{~min}$ to linearize mRNA and then placed on ice for $2 \mathrm{~min}$. To each tube was added: $10 \times \mathrm{RT}$ buffer $(1 \mu \mathrm{l}), \mathrm{MgCl}_{2}(2 \mu \mathrm{l}, 25$ $\mathrm{mm})$, DTT (1 $\mu \mathrm{l}, 0.1 \mathrm{M})$, RNase Out $(0.5 \mu \mathrm{l})$, and $200 \mathrm{U}$ of Superscript II reverse transcriptase. cDNA transcription was performed by heating the reaction mixture to $25^{\circ} \mathrm{C}$ for $10 \mathrm{~min}$ and $42^{\circ} \mathrm{C}$ for $50 \mathrm{~min}$. The reaction is terminated by incubation at $70^{\circ} \mathrm{C}$ for $15 \mathrm{~min}$ and then placed on ice. RNA 
was then removed by adding $0.5 \mu 1 \mathrm{RNAseH}$ to each tube and incubating for $20 \mathrm{~min}$ at $37^{\circ} \mathrm{C}$.

Transcript cDNA was amplified using a two round strategy. In the first round, a nested PCR reaction was performed to amplify $5-\mathrm{HT}_{2 \mathrm{a}}$ and $5-\mathrm{HT}_{2 \mathrm{c}}$ receptors. Reaction mixtures contained $2.5 \mathrm{mM} \mathrm{MgCl}_{2}, 0.5 \mathrm{~mm}$ each of dATP, dCTP, dGTP, and dTTP, $1 \mu \mathrm{M}$ primers, $10 \times$ buffer, 2.5 $\mathrm{U}$ of TaqDNA polymerase, and $4 \mu \mathrm{l}$ of the cDNA from the single-cell RT reaction. All PCR reagents were obtained from Promega (Madison, WI). The reaction mixtures were heated to $94^{\circ} \mathrm{C}$ for $30 \mathrm{sec}, 52^{\circ} \mathrm{C}$ for $45 \mathrm{sec}$, and $72^{\circ} \mathrm{C}$ for $90 \mathrm{sec}$ for 30 cycles. Two microliters of product from the first round PCR reaction was used in a second round to amplify the specific 5- $\mathrm{HT}_{2}$ receptor amplicons. The thermal cycling program for the second round of amplification was $94^{\circ} \mathrm{C}$ for $30 \mathrm{sec}, 56^{\circ} \mathrm{C}$ for $45 \mathrm{sec}$, and $72^{\circ} \mathrm{C}$ for $90 \mathrm{sec}$ for 45 cycles. PCR primers were developed using GenBank sequences using Oligo software (National Biosciences, Plymouth, MA) and synthesized by Invitrogen. The primers used in the first round of amplification were 5': GCC ATW GCT GAT ATG CTG; 3' and $5^{\prime}$ : CCA SAC AAA CAC ATT GAG; $3^{\prime}$. For the second round of amplification the primer sequences were: $5-\mathrm{HT}_{2 \mathrm{a}}$ (GenBank accession number M30705) 5': ATT GCC GTG TGG ACC ATA TCTG; $3^{\prime}$ and 5': GCA GGA TTC TTT GCA GAT GACG-3'; 5-HT $2 \mathrm{c}$ (GenBank accession number M21410) 5': GCC ATC ATG AAG ATT GCC ATCG; 3' and 5': CGA CGT GGT TTC TGA TCT GGAT-3'; calmodulindependent kinase type II (CaMKII; GenBank accession number J02942) 5': ACA AGA AGA ATG ATG GCG TGA AGG; $3^{\prime}$ and 5': CCA GGT ACT GAG TGA TGC GGA TGT-3'. These primer sequences have been published previously (Vysokanov et al., 1998; Feng et al., 2001). After amplification, PCR products were labeled by ethidium bromide and separated by electrophoresis on agarose gels.

Negative controls for extraneous and genomic DNA contamination were run for each experiment. To verify that genomic DNA was not being amplified, reverse transcriptase was omitted from one neuron during the RT reaction, and the resulting reaction mixture was processed for PCR amplification as described above. Extraneous contamination during the PCR amplification was examined by replacing the cDNA template with buffer solution. Both controls consistently yield negative results during these experiments.

\section{RESULTS}

\section{$5-\mathrm{HT}_{2 \mathrm{a} / \mathrm{c}}$ receptor stimulation reduces rapidly inactivating $\mathrm{Na}^{+}$currents in PFC pyramidal cells}

Application of 5-HT produced a dose-dependent $(0.01-10 \mu \mathrm{M})$ and reversible reduction in the peak amplitude of rapidly inactivating $\mathrm{Na}^{+}$currents evoked by a step from a holding potential of $-70 \mathrm{mV}$ to a command potential of $-35 \mathrm{mV}$ (Fig. 1A). At saturating concentrations $(1 \mu \mathrm{M})$, the mean reduction of peak $\mathrm{Na}^{+}$current was $24.2 \pm 1.9 \%(n=10)$. Pooled data across the range of 5-HT concentrations were fit with a Langmuir isotherm, yielding an $\mathrm{EC}_{50}$ of $132 \mathrm{~nm}$ (Fig. $1 B$ ). The effect of 5-HT on rapidly inactivating $\mathrm{Na}^{+}$currents was mediated in part by a decrease in peak whole-cell $\mathrm{Na}^{+}$conductance. In addition, application of 5-HT produced a consistent negative shift in the voltage dependence of fast inactivation $\left[V_{1 / 2}(\right.$ control $)=-55.1 \mathrm{mV}$ $(-52.4-59.3 \mathrm{mV}) ; V_{1 / 2}(5-\mathrm{HT}, 1 \mu \mathrm{M})=-64.9 \mathrm{mV}(-60.9-67.5$ $\mathrm{mV}$ ); $n=6 ; p<0.005$; Kruskal-Wallis] (Fig. 2) that reversed after wash. There was no significant change in the voltage dependence of activation (data not shown).

Single-cell reverse transcription (scRT-PCR) analysis revealed that the majority of PFC pyramidal neurons expressed detectable levels of $5-\mathrm{HT}_{2 \mathrm{a}}$ and/or $5-\mathrm{HT}_{2 \mathrm{c}}$ receptor mRNA (Fig. 1C). In a sample of 46 cells, $53 \%$ (25 of 46) had detectable levels of mRNA for both $5-\mathrm{HT}_{2 \mathrm{a}}$ and $5-\mathrm{HT}_{2 \mathrm{c}}$ receptors. $5-\mathrm{HT}_{2 \mathrm{a}}$ receptor mRNA alone was detected in $39 \%$ (18 of 46), and one cell (2\%) contained mRNA for $5-\mathrm{HT}_{2 \mathrm{c}}$ alone. These results suggest a near ubiquitous expression of $5-\mathrm{HT}_{2}$ class receptors in PFC pyramidal cells, with $5-\mathrm{HT}_{2 \mathrm{a}}$ being the predominantly expressed member of this family.

To examine the role of $5-\mathrm{HT}_{2 \mathrm{a} / \mathrm{c}}$ receptor stimulation in the
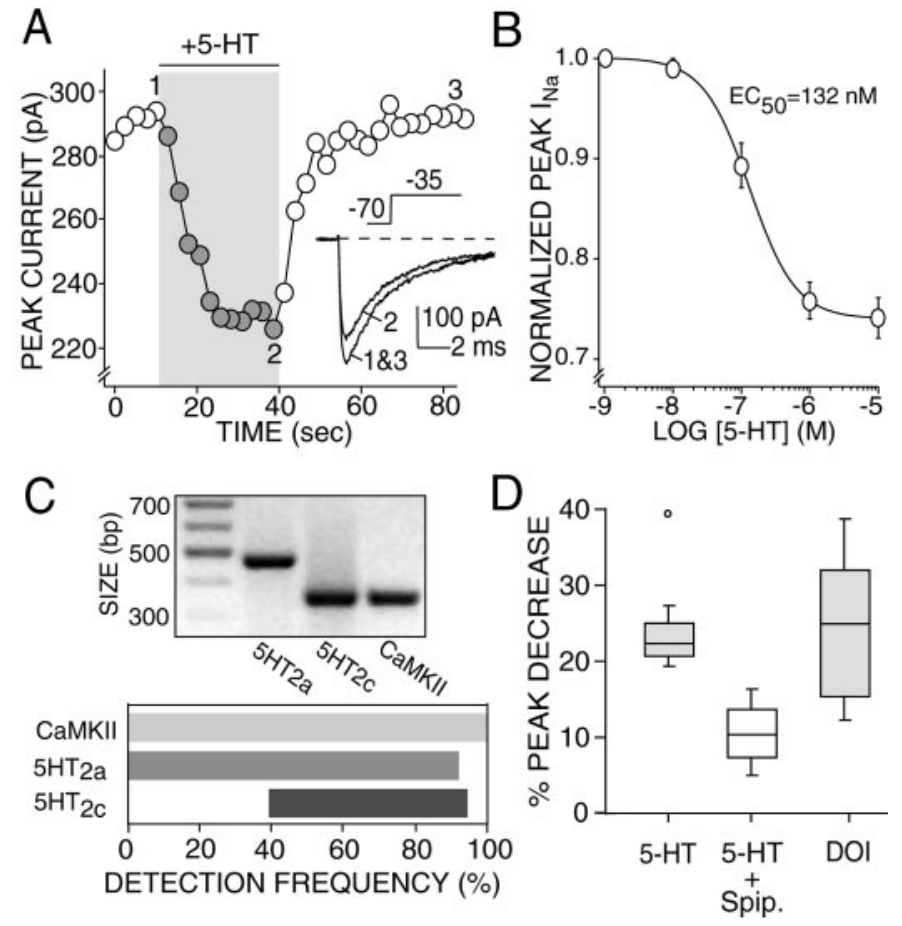

Figure 1. 5- $\mathrm{HT}_{2 \mathrm{a} / \mathrm{c}}$ receptor stimulation reduces rapidly inactivating $\mathrm{Na}^{+}$ current in PFC pyramidal cells. $A$, Plot of peak $\mathrm{Na}^{+}$current evoked by a step from a holding potential of -70 to $-35 \mathrm{mV}$ as a function of time. Application of 5-HT $(1 \mu \mathrm{M})$ reversibly suppressed peak $\mathrm{Na}^{+}$current. $B$, Dose-response curve for 5-HT-mediated reduction in current. The curve represents the least squares fit of a Langmuir isotherm to the data with a $\mathrm{EC}_{50}$ of 132 nM. $C$, Single-cell RT-PCR revealed that the majority of PFC neurons express $5-\mathrm{HT}_{2 \mathrm{a}}$ and/or $5-\mathrm{HT}_{2 \mathrm{c}}$ receptor mRNA. In a representative gel, a single PFC pyramidal cell expresses mRNA for $\mathrm{Ca}^{2+}$ calmodulin kinase II (CaMKII) as well as amplicons for both $5-\mathrm{HT}_{2 \mathrm{a}}$ and $5-\mathrm{HT}_{2 \mathrm{c}}$. Frequency distribution of mRNA for CaMKII, $5 \mathrm{HT}_{2 \mathrm{a}}$, and $5 \mathrm{HT}_{2 \mathrm{c}}$ receptors in 46 PFC pyramidal cells. $D$, Box plot summary of the effect of 5-HT agonists and antagonists on peak $\mathrm{Na}^{+}$current. The effect of 5-HT ( $1 \mu \mathrm{M}, n=10)$ was significantly reduced when coapplied with the $5 \mathrm{HT}_{2 \mathrm{a} / \mathrm{c}}$ antagonist spiperone $(1 \mu \mathrm{M}, n=8)$. The effect of 5 -HT was mimicked by the $5-\mathrm{HT}_{2 \mathrm{a} / \mathrm{c}}$ agonist DOI $(10 \mu \mathrm{M}, n=19)$.

effects of 5-HT on rapidly inactivating $\mathrm{Na}^{+}$currents, 5-HT was applied in the presence and absence of the $5-\mathrm{HT}_{2 \mathrm{a} / \mathrm{c}}$ antagonist spiperone (Fig. 1D). In the presence of spiperone $(1 \mu \mathrm{M})$ the effect of equimolar concentrations of 5-HT on peak $\mathrm{Na}^{+}$current was significantly reduced [average peak reduction, $10.5 \%(8.8-$ $11.7 \%), n=8 ; p<0.001$ Kruskal-Wallis]. The $5-\mathrm{HT}_{2 \mathrm{a} / \mathrm{c}}$ receptor specific agonist DOI also reduced peak $\mathrm{Na}^{+}$currents to a similar extent as 5-HT (Fig. 1D). The average reduction of peak $\mathrm{Na}^{+}$ current produced by $10 \mu \mathrm{M}$ DOI was $25.5 \pm 2.9 \%(n=19)$. This response was also reversible and dose dependent $(0.01-30 \mu \mathrm{M})$. Similar to 5-HT, DOI also induced a negative shift in the voltage dependence of fast inactivation $\left[V_{1 / 2}(\right.$ control $)=-63.1 \pm 1.3 \mathrm{mV}$; $V_{1 / 2}(\mathrm{DOI}, 10 \mu \mathrm{M})=-70.4 \pm 1.3 \mathrm{mV} ; n=14 ; p<0.005$; paired $t$ test] (Fig. 2D, inset) that reversed after wash. DOI did not produce a significant change in the voltage dependence of activation (data not shown).

Previous work in cultured neurons and in acutely dissociated hippocampal pyramidal cells has shown that activation of G-protein-coupled receptors and PKC stimulation can slow $\mathrm{Na}^{+}$ channel inactivation kinetics (Cantrell and Catterall, 2001). To examine whether $5-\mathrm{HT}_{2 \mathrm{a} / \mathrm{c}}$ receptor stimulation slowed $\mathrm{Na}^{+}$current inactivation in PFC neurons, we measured the inactivation 


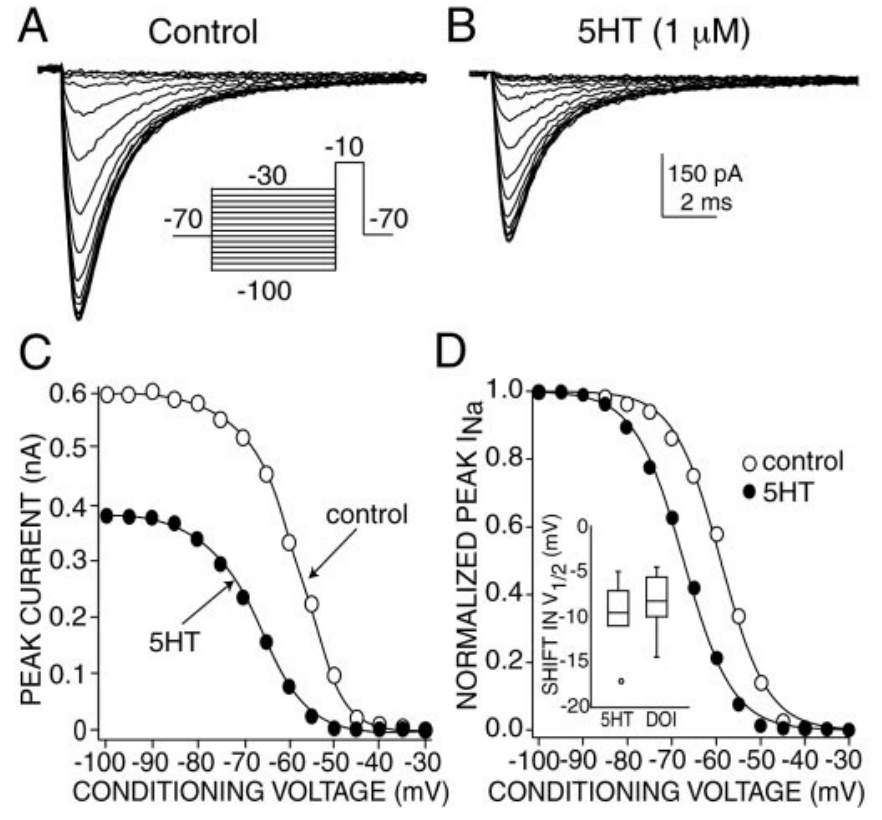

Figure 2. 5- $\mathrm{HT}_{2 \mathrm{a} / \mathrm{c}}$ receptor stimulation shifts the voltage dependence of steady-state inactivation to more negative potentials. $A$, In a representative cell, TTX-subtracted $\mathrm{Na}^{+}$currents evoked by a step to $-10 \mathrm{mV}$ from a range of conditioning voltages (inset). $B$, Currents from the same cell in the presence of $1 \mu \mathrm{M} 5$-HT. $C$, Steady-state inactivation plot showing the peak amplitude of the $\mathrm{Na}^{+}$currents shown in $A$ (open circles) and $B$ (closed circles). 5-HT $(1 \mu \mathrm{M})$ reduced peak $\mathrm{Na}^{+}$current and shifted the voltage dependence of steady-state inactivation to more negative potentials. $D$, The negative shift in $V_{1 / 2}$ is more pronounced when plotting the normalized peak current $\left(I / I_{\max }\right)$ of the same data shown in $C$. Inset, Box plot summary of the shift in $V_{1 / 2}$ produced by 5 -HT $(1 \mu \mathrm{M}, n=6)$ and DOI $(10 \mu \mathrm{M}, n=14)$.

time constants of currents in the presence and absence of DOI $(10 \mu \mathrm{M})$. Currents were fit using a modified Hodgkin-Huxley equation possessing two inactivation time constants (see Materials and Methods). Inactivation kinetics of currents evoked by weak $(-50 \mathrm{mV})$ and strong depolarizations $(0 \mathrm{mV})$ were examined as were currents evoked from hyperpolarized $(-100 \mathrm{mV})$ and relatively depolarized $(-70 \mathrm{mV})$ holding potentials. Although DOI reduced the rapidly inactivating $\mathrm{Na}^{+}$currents in all of these protocols, the fast $\left(\tau_{\text {fast }}\right)$ and slow $\left(\tau_{\text {slow }}\right)$ inactivation time constants were unchanged in any of these conditions (Fig. 3B,C).

\section{$5-\mathrm{HT}_{2 \mathrm{a} / \mathrm{c}}$ receptor modulation of $\mathrm{Na}^{+}$currents requires activation of $a \mathbf{G}_{\mathrm{q}}-\mathrm{PLC}-\mathrm{PKC}$ signaling cascade}

The best characterized signal transduction pathway activated $5-\mathrm{HT}_{2 \mathrm{a} / \mathrm{c}}$ receptors relies on $\mathrm{G} \alpha_{\mathrm{q}}$ stimulation of phospholipase $\mathrm{C} \beta$ isoforms (PLC $\beta$ ) (Sanders-Bush and Canton, 1995). PLC $\beta$ hydrolyzes phosphatidylinositol 4,5-bisphosphate to form diacylglycerol (DAG) and inositol 1,4,5-triphosphate $\left(\mathrm{IP}_{3}\right)$. DAG, in turn, activates PKC, which has been shown to modulate $\mathrm{Na}^{+}$ channels in a variety of neural systems (Cantrell and Catterall, 2001). To examine whether the $5-\mathrm{HT}_{2 \mathrm{a} / \mathrm{c}}$ receptor-mediated inhibition of $\mathrm{Na}^{+}$currents depended on activation of $\mathrm{G} \alpha$, PFC neurons were dialyzed with a peptide that mimics the $\mathrm{C}$ terminal binding site of $\mathrm{G} \alpha_{\mathrm{q}}$ (Akhter et al., 1998). This peptide blocks the interaction between $5-\mathrm{HT}_{2 \mathrm{a} / \mathrm{c}}$ receptors and $\mathrm{G} \alpha_{\mathrm{q}}$ proteins. In cells dialyzed with this peptide $(100 \mu \mathrm{M})$, the DOI-mediated reduction of $\mathrm{Na}^{+}$currents was significantly reduced when compared with cells dialyzed with the same concentration of a nonsense peptide of equal size [average peak reduction ( $\mathrm{G} \alpha_{\mathrm{q}}$ peptide) $0.8 \%$ (0-

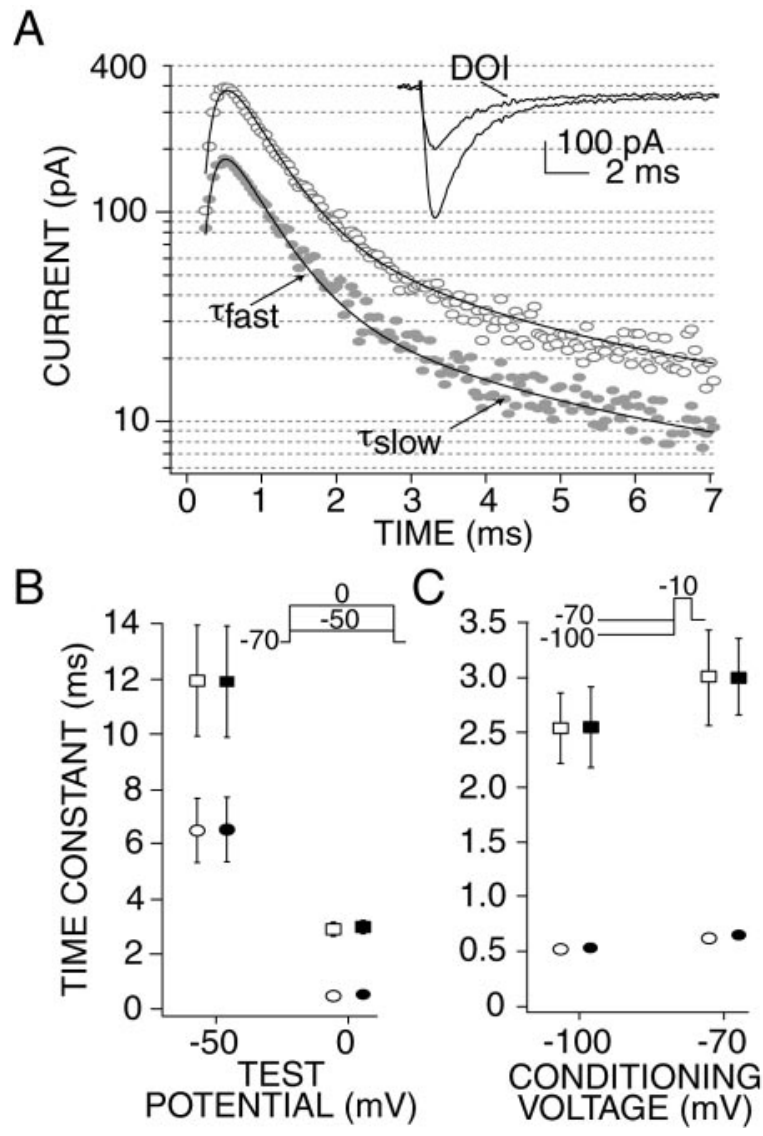

Figure 3. $5-\mathrm{HT}_{2 \mathrm{a} / \mathrm{c}}$ receptor stimulation does not alter the inactivation time constants of rapidly inactivating $\mathrm{Na}^{+}$currents. $A$, Current traces evoked by a step to $-10 \mathrm{mV}$ from a holding potential of $-70 \mathrm{mV}$ in the presence ( filled circles) or absence (open circles) of $10 \mu \mathrm{M}$ DOI. Current amplitude is plotted on an inverted semi-log scale to illustrate the biexponential character of the current inactivation. The same traces are also shown in the inset in a more standard form for comparison purposes. The control curve (top line) represents the best fit of a modified HodgkinHuxley model (see Materials and Methods). The DOI curve (bottom line) uses the values of activation and inactivation time constants obtained from the control curve, changing only $g_{\max }$ and $I_{\mathrm{NaP}}$. The SE of the resulting curve does not differ significantly from the control curve. $B, C$, Fast (circles) and slow (squares) inactivation time constants obtained by applying similar curve fits to currents derived from activation $(B)$ and inactivation $(C)$ protocols in the presence ( filled symbols) and absence (open symbols) of $10 \mu \mathrm{M}$ DOI. DOI did not produce a significant change in either the fast or slow inactivation time constants of $\mathrm{Na}^{+}$currents obtained by either voltage protocol $(n=5)$. Two representative test voltages $(B)$ or conditioning voltages $(C)$ are presented in each graph.

5.4\%), $n=8$; (nonsense peptide) $21.2 \%(18.3-26.3 \%), n=8 ; p<$ 0.001; Kruskal-Wallis] (Fig. 4A,B). Dialysis with the $\mathrm{G} \alpha$ q peptide also prevented the DOI-induced negative shift in the voltage dependence of fast inactivation [average shift in $V_{1 / 2}\left(\mathrm{G} \alpha_{\mathrm{q}}\right.$ peptide) $-1.8 \mathrm{mV}(-1.7-1.8 \mathrm{mV}), n=7$; (nonsense peptide) -7.1 $\mathrm{mV}$ ( -7 to $7.1 \mathrm{mV}$ ), $n=8 ; p<0.001$; Kruskal-Wallis] (Fig. $4 C$ ).

To determine if the activation of PLC $\beta$ is required for the DOI-induced inhibition of rapidly inactivating $\mathrm{Na}^{+}$currents, neurons were dialyzed with the PLC inhibitor U-73122 $(20 \mu \mathrm{M})$. U-73122 $(0.2 \mu \mathrm{M})$ was also perfused in the extracellular bathing media. Under these conditions, the DOI-mediated reduction of $\mathrm{Na}^{+}$currents was significantly reduced when compared with cells dialyzed and perfused with the less active PLC inhibitor U-73343 [average peak reduction (U-73122) 4.6\% (4.1-5.4\%), $n=8$; 
Figure 4. $5-\mathrm{HT}_{2 \mathrm{a} / \mathrm{c}}$ receptor modulation of peak $\mathrm{Na}^{+}$current depends on activation of $\mathrm{G} \alpha_{\mathrm{q}}$ and PLC. $A$, In neurons dialyzed with a peptide $(100 \mu \mathrm{M})$ that blocks binding of $\mathrm{G} \alpha_{\mathrm{q}}$, DOI $(10 \mu \mathrm{M})$ failed to significantly reduce peak $\mathrm{Na}^{+}$current. $B$, Box plot summary of the reduction in peak $\mathrm{Na}^{+}$current by DOI in cells dialyzed with the $\mathrm{G} \alpha_{\mathrm{q}}$ peptide $(n=8)$ or a nonsense peptide of equal size $(n=8)$. $C$, Blockade of $\mathrm{G} \alpha_{\mathrm{q}}$ also prevents the negative shift in the voltage dependence of steady-state inactivation produced by DOI. Inset, Box plot summary of the shift in $V_{1 / 2}$ by DOI in cells dialyzed with the $\mathrm{G} \alpha_{\mathrm{q}}$ peptide $(n=7)$ or a nonsense peptide $(n=8)$. $D$, Dialysis with the PLC inhibitor U-73122 $(20 \mu \mathrm{M})$ blocks the reduction in peak $\mathrm{Na}^{+}$current by DOI. U-73122 $(0.2 \mu \mathrm{M})$ was also included in the extracellular bathing solution. $E$, Box plot summary of the reduction in peak $\mathrm{Na}^{+}$ current by DOI in cells dialyzed with U-73122 $(n=8)$ or the weak PLC inhibitor U-73343 $(n=7) . F$, Dialysis with U-73122 also prevents the negative shift in the voltage dependence of steady-state inactivation induced by $5-\mathrm{HT}_{2 \mathrm{a} / \mathrm{c}}$ receptor activation. Inset, Box plot summary of the shift in $V_{1 / 2}$ by DOI in cells dialyzed with U-73122 $(n=5)$ or the weak PLC inhibitor U-73343 $(n=6)$.
A

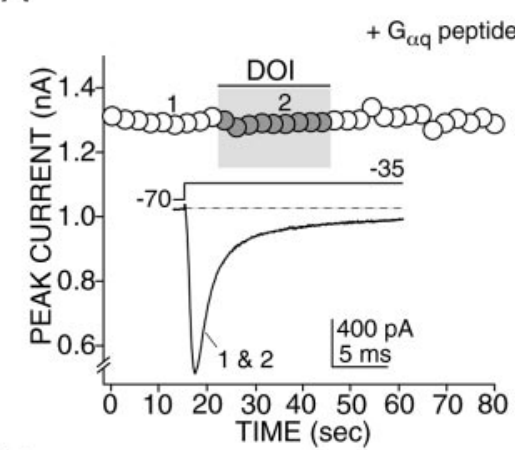

D

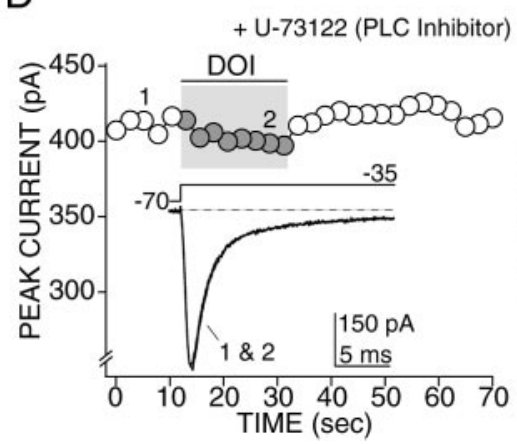

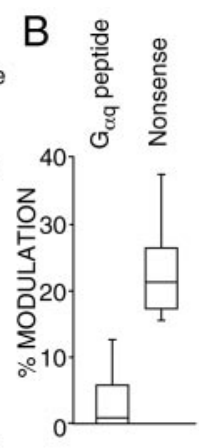

C
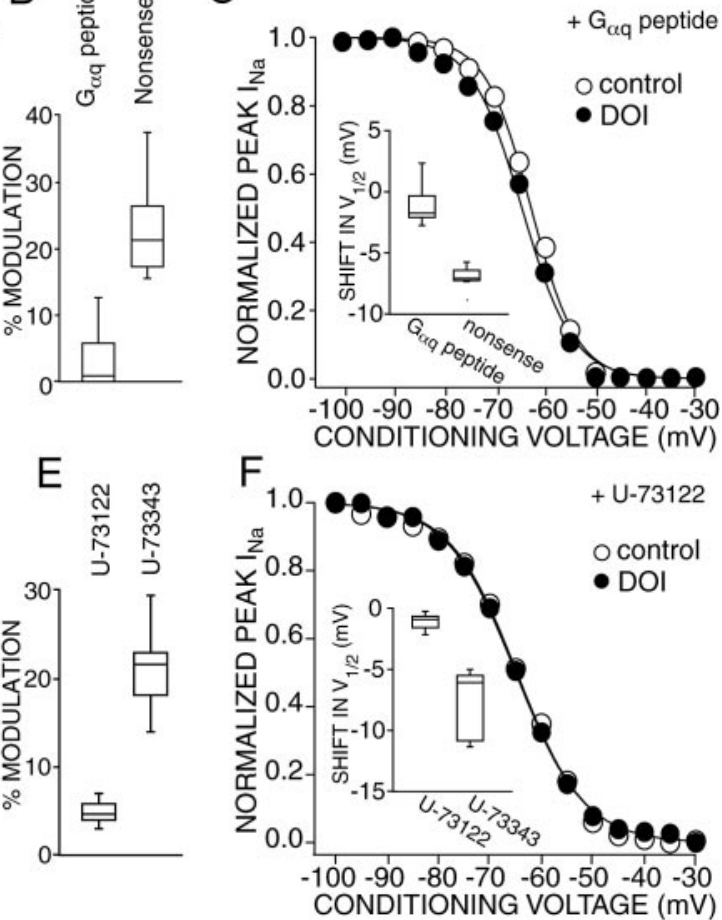

(U-73343) 21.6\% (18.9-23.6\%), $n=7 ; p<0.001$; KruskalWallis] (Fig. 4D,E). Dialysis with U-73122 also prevented the DOI-induced negative shift in the voltage dependence of fast inactivation [average shift in $V_{1 / 2}$ (U-73122) $-1.0 \mathrm{mV}(-0.7-1.6$ $\mathrm{mV}), n=5$; (U-73343) $-6.1 \mathrm{mV}(-5.5-10.8 \mathrm{mV}), n=6 ; p<$ 0.005; Kruskal-Wallis] (Fig. $4 F$ ).

Previous reports have demonstrated that activation of PKC produces a reduction in peak $\mathrm{Na}^{+}$conductance after the removal of fast inactivation (Cantrell and Catterall, 2001). In some cell types, PKC activation also shifts the voltage dependence of fast inactivation (Goody and Cukierman, 1994; Franceschetti et al., 2000). Consistent with the hypothesis that the $5-\mathrm{HT}_{2 \mathrm{a} / \mathrm{c}}$ receptorinduced reduction of $\mathrm{Na}^{+}$currents is mediated by $\mathrm{PKC}$, dialysis with the PKC inhibitor calphostin $\mathrm{C}(1 \mu \mathrm{M})$ prevented the reduction in peak $\mathrm{Na}^{+}$current produced by DOI [average peak reduction (control) $25.5 \pm 2.9 \%, n=19$; (calphostin) $2.4 \%(0.5-4.3 \%)$, $n=6 ; p<0.001$; Kruskal-Wallis] (Fig. 5A). Dialysis with calphostin $\mathrm{C}$ also prevented the DOI-induced negative shift in the voltage dependence of fast inactivation [average shift in $V_{1 / 2}$ (control) $-7.3 \pm 1.4 \mathrm{mV}, n=14$; (calphostin) $-1.4 \mathrm{mV}(-0.6-$ $2.1 \mathrm{mV}$ ), $n=6 ; p<0.005$; Kruskal-Wallis] (Fig. 5A,B). As with receptor activation, direct stimulation of $\mathrm{PKC}$ using the membrane-permeable activator OAG $(2 \mu \mathrm{M})$ significantly reduced the peak amplitude of rapidly inactivating $\mathrm{Na}^{+}$currents (Fig. 6A,B), without altering their inactivation kinetics (data not shown). This reduction in peak $\mathrm{Na}^{+}$by OAG was significantly reduced in neurons dialyzed with the PKC inhibitor calphostin (1 $\mu \mathrm{M})$ (Fig. 6B). OAG also induced a significant negative shift in the voltage dependence of fast inactivation $\left[V_{1 / 2}\right.$ (control) $=$ $-56.6 \mathrm{mV}(-55.4-55.6 \mathrm{mV}) ; V_{1 / 2}(\mathrm{OAG}, 2 \mu \mathrm{M})=-71.9 \mathrm{mV}$ (-62.1-75.9 mV); $n=7 ; p<0.005$; Kruskal-Wallis] (Fig. 6C,D).

To date, at least 11 isoforms of PKC have been identified. These isoforms have been classified in to three principal families based on their structure and sensitivity to activation by cofactors such as $\mathrm{Ca}^{2+}$ and phospholipids (Liu and Heckman, 1998). To determine if the $5-\mathrm{HT}_{2 \mathrm{a} / \mathrm{c}}$ receptor-induced reduction of $\mathrm{Na}^{+}$ currents requires a $\mathrm{Ca}^{2+-}$ sensitive $\mathrm{PKC}$, neurons were dialyzed with the $\mathrm{Ca}^{2+}$ chelator BAPTA $(20 \mathrm{~mm})$. Dialysis with BAPTA significantly attenuated the DOI-mediated reduction of peak $\mathrm{Na}^{+}$ currents [average peak reduction (BAPTA) 7.0\% (3.0-8.5\%), $n=9$; (control) $25.5 \pm 2.9 \%, n=19 ; p<0.001$ Kruskal-Wallis] (Fig. 5D,E). Dialysis with BAPTA also prevented the DOIinduced negative shift in the voltage dependence of fast inactivation [average shift in $V_{1 / 2}$ (control) $-7.3 \pm 1.4 \mathrm{mV}, n=14$; (BAPTA) $-1.1 \mathrm{mV}(-0.8-2.1 \mathrm{mV}), n=5$; $p<0.005$; KruskalWallis] (Fig. 5F).

\section{$5-\mathrm{HT}_{2 \mathrm{a} / \mathrm{c}}$ receptor stimulation modulates persistent $\mathrm{Na}^{+}$currents via a PKC-dependent mechanism}

In addition to rapidly inactivating currents, PFC pyramidal neurons exhibit a prominent persistent $\mathrm{Na}^{+}$current (Maurice et al., 2001). Estimates of the persistent conductance as a function of membrane potential were fit well with a Boltzmann function of form similar to that of the rapidly inactivating currents. As in a number of other neurons (Crill, 1996), the persistent current had a half-activation voltage that was substantially more negative $(\sim 10 \mathrm{mV})$ than that of the rapidly inactivating current $\left[V_{1 / 2}\right.$ (persist.) $-52.1 \pm 1.1 \mathrm{mV} ; V_{1 / 2}$ (fast) $\left.-43.1 \pm 0.8 \mathrm{mV}\right]$. DOI $(10$ $\mu \mathrm{M})$ significantly reduced the persistent $\mathrm{Na}^{+}$current measured with slow $(35 \mathrm{mV} / \mathrm{sec})$ voltage ramps in physiological concentrations of $\mathrm{Na}^{+}(115 \mathrm{~mm})$ (Fig. $\left.7 A, B\right)$. The amplitude of the persistent current was measured at $-25 \mathrm{mV}$, to avoid confusion with the window current. The persistent $\mathrm{Na}^{+}$current was reduced by DOI in all cells examined [average reduction, $39.4 \pm 2.5 \% ; n=$ 10] (Fig. 7B). DOI did not significantly alter the activation voltage dependence of the persistent current $\left[V_{1 / 2}\right.$ (control) $-52.1 \pm 1.1$ $\mathrm{mV} ; V_{1 / 2}(\mathrm{DOI})-52.5 \pm 1.1 \mathrm{mV} ; p>0.05$; Kruskal-Wallis] (Fig. $7 C)$. DOI $(10 \mu \mathrm{M})$ also significantly reduced the persistent current measured at the end of a $40 \mathrm{msec}$ voltage step [average reduction, $37.6 \pm 2.8 \%, n=10$ ] (Fig. $7 D$ ). As with the modulation of rapidly 
A
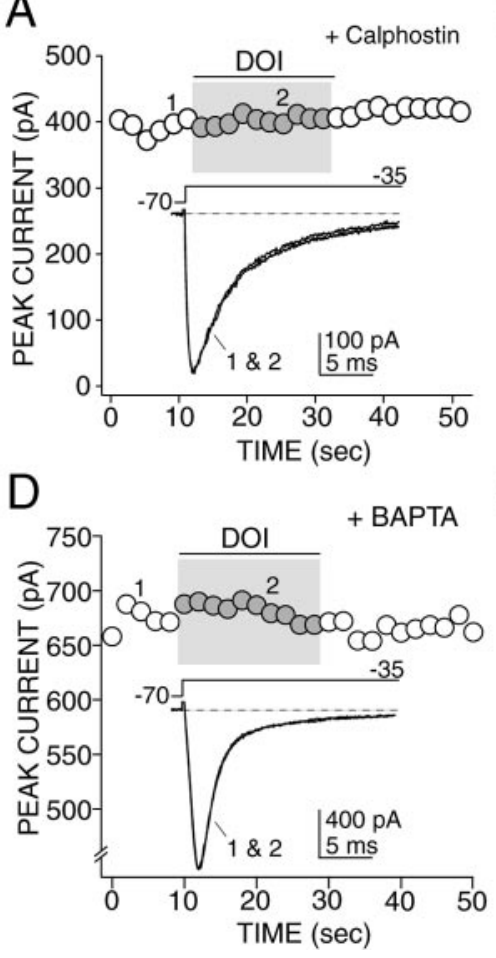

B

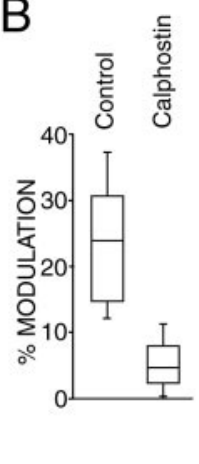

$E$

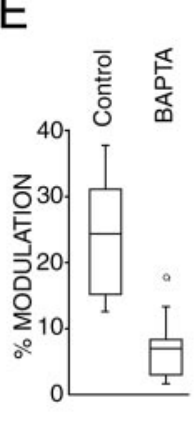

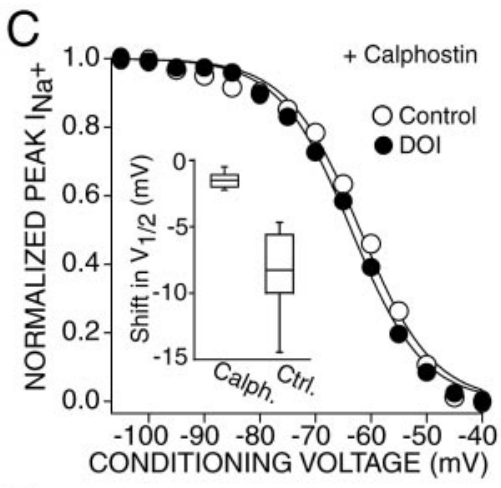

$\mathrm{F}$

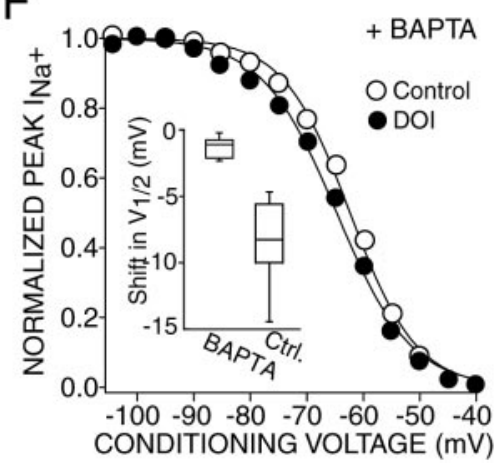

Figure 5. 5- $\mathrm{HT}_{2 \mathrm{a} / \mathrm{c}}$ receptor modulation of peak $\mathrm{Na}^{+}$current depends on activation of $\mathrm{PKC}$ and elevation in intracellular calcium. $A, D$, Dialysis with the PKC inhibitor calphostin C $(1 \mu \mathrm{M})$ or with the calcium chelator BAPTA $(20 \mathrm{~mm})$ blocks the reduction in peak $\mathrm{Na}^{+}$current by DOI $(10 \mu \mathrm{M}) . B, E$, Box plot summaries of the reduction in peak $\mathrm{Na}^{+}$current by DOI in control cells $(n=19)$ and in cells dialyzed with calphostin $(n=6)$ in $B$ or with BAPTA $(n=9)$ in $E$. $C, F$, Dialysis with either calphostin or BAPTA also prevents the negative shift in the voltage dependence of steady-state inactivation induced by $5-\mathrm{HT}_{2 \mathrm{a} / \mathrm{c}}$ receptor activation. Insets, Box plot summaries of the shift in $V_{1 / 2}$ by DOI in control cells $(n=14)$ and in cells dialyzed with calphostin $(n=$ $6)$ in $C$ or with BAPTA $(n=5)$ in $F$. inactivating $\mathrm{Na}^{+}$current, $5-\mathrm{HT}_{2 \mathrm{a} / \mathrm{c}}$ receptor-induced reduction of persistent $\mathrm{Na}^{+}$current was PKC dependent. Dialysis with the PKC inhibitor calphostin $(1 \mu \mathrm{M})$ attenuated the effect of DOI on persistent $\mathrm{Na}^{+}$current measured with slow voltage ramps [average reduction, $8.6 \%(6.7-10 \%) ; n=7 ; p<0.005$; KruskalWallis] (Fig. 7E). Direct stimulation of PKC with OAG $(2 \mu \mathrm{M})$ also produced a marked reduction in the amplitude of persistent $\mathrm{Na}^{+}$current evoked by either a step pulse [average reduction, $58.5 \%(50.5-76 \%) ; n=6$ ] or a slow voltage ramp [average reduction, $76.3 \%(54.2-79.2 \%) ; n=5$ ] (Fig. 7E) without altering activation voltage dependence.

\section{$5-\mathrm{HT}_{2 \mathrm{a} / \mathrm{c}}$ receptor stimulation attenuates spikes backpropagating into the apical dendrite of deep layer pyramidal neurons}

Backpropagation of spikes into the dendritic tree of pyramidal neurons is dependent on voltage-dependent $\mathrm{Na}^{+}$channels (Stuart and Sakmann, 1994). The reduction of $\mathrm{Na}^{+}$channel currents by $5-\mathrm{HT}_{2}$ receptor activation should reduce the safety factor for this invasion, leading to an attenuation of the action potential at dendritic loci. To test this hypothesis, dual whole-cell currentclamp recordings were obtained from the soma and apical dendrite (100-160 $\mu \mathrm{M}$ from the soma) of layer V pyramidal cells in PFC slices $(n=6)$. Application of DOI $(1 \mu \mathrm{M})$ did not alter the resting membrane potential in either the soma $\left[V_{\mathrm{m}}\right.$ (control) $68.7 \pm 1.5 \mathrm{mV}$; (DOI) $68.2 \pm 1.4 \mathrm{mV}]$ or the apical dendrite $\left[V_{\mathrm{m}}\right.$ (control) $69.2 \pm 3.7 \mathrm{mV}$; (DOI) $70.0 \pm 4.6 \mathrm{mV}$ ]. Action potentials were initiated by brief somatic current injection. The amplitude of the dendritic action potential was significantly smaller than the somatic action potential [amplitude (soma) $72.7 \pm 7.9 \mathrm{mV}$; (dendrite) $58.0 \pm 5.0 \mathrm{mV}$; $p<0.03$ one-tailed Mann-Whitney $U$ test] (Fig. 8A,C). Whereas DOI had no effect on the amplitude of somatic spikes [amplitude (control) $72.7 \pm 7.9 \mathrm{mV}$; (DOI) $71.3 \pm$ $7.6 \mathrm{mV}$ ] it significantly decreased dendritic spike amplitude [amplitude (control) $58.0 \pm 5.0 \mathrm{mV}$; (DOI) $44.8 \pm 5.3 \mathrm{mV} ; p<0.03$; two-tailed Wilcoxon signed rank test for correlated groups] (Fig. 8). DOI also produced a significant slowing of the action potential rise time in the dendrite $[\Delta V / \Delta t$ (control) $195.1 \pm 50 \mathrm{mV} / \mathrm{msec}$; (DOI) $160.5 \pm 46.5 \mathrm{mV} / \mathrm{msec} ; p<0.05$, two-tailed Wilcoxon signed rank test for correlated groups] but not soma $[\Delta V / \Delta t$ (control) $313 \pm 44 \mathrm{mV} / \mathrm{msec}$; (DOI) $310 \pm 45 \mathrm{mV} / \mathrm{msec}]$ (Fig. $8 A, B)$.

\section{DISCUSSION}

$5-\mathrm{HT}_{2 \mathrm{a} / \mathrm{c}}$ receptor stimulation reduces rapidly inactivating $\mathrm{Na}^{+}$current via a $\mathrm{G}_{\mathrm{q}}-\mathrm{PLC}-\mathrm{PKC}$-dependent signaling pathway

Activating through 5- $\mathrm{HT}_{2 \mathrm{a} / \mathrm{c}}$ receptors, 5-HT reduces rapidly inactivating $\mathrm{Na}^{+}$current in PFC pyramidal neurons. The ability of the $5-\mathrm{HT}_{2 \mathrm{a} / \mathrm{c}}$ antagonist spiperone to antagonize the effect of 5-HT, the similar response produced by the $5-\mathrm{HT}_{2 \mathrm{a} / \mathrm{c}}$ agonist DOI, and the expression of $5-\mathrm{HT}_{2 \mathrm{a}}$ and/or $5-\mathrm{HT}_{2 \mathrm{c}}$ receptor mRNA in the vast majority of PFC pyramidal neurons support the conclusion that this effect is mediated by $5-\mathrm{HT}_{2 \mathrm{a} / \mathrm{c}}$ receptors. Our scRT-PCR observations indicate that $5-\mathrm{HT}_{2 \mathrm{a}}$ is the predominant $5-\mathrm{HT}_{2}$ class receptor subtype in PFC pyramidal neurons, consistent with previous observations (Feng et al., 2001). It is possible that the observed effects on $\mathrm{Na}^{+}$currents are mediated exclusively by $5-\mathrm{HT}_{2 \mathrm{a}}$ receptors. This hypothesis is based on the observation that $5-\mathrm{HT}_{2 \mathrm{c}}$ receptor mRNA was detected in less than half of the cells sampled while the effects of DOI or 5-HT were qualitatively similar in all recorded neurons. However, given the similar pharmacological profiles (Glennon and Dukat, 1995) and intracellular signaling cascades (Sanders-Bush and Canton, 1995) of 5-HT $\mathrm{Ha}_{2 \mathrm{a}}$ and $5-\mathrm{HT}_{2 \mathrm{c}}$ receptor subtypes, a contribution of $5-\mathrm{HT}_{2 \mathrm{c}}$ cannot be excluded.

Both $5-\mathrm{HT}_{2 \mathrm{a}}$ and $5-\mathrm{HT}_{2 \mathrm{c}}$ receptors are positively coupled to PLC $\beta$ isoforms via $\mathrm{G} \alpha_{\mathrm{q}}$ leading to downstream activation of PKC (Sanders-Bush and Canton, 1995). Previous work by our group 
A

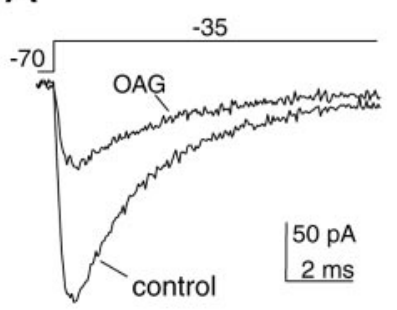

C

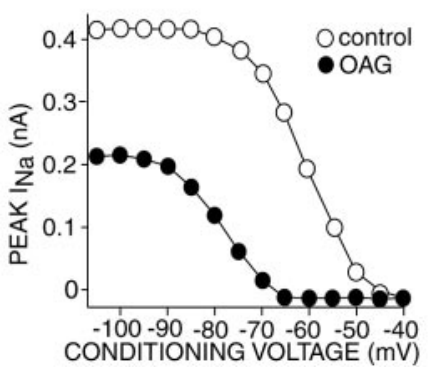

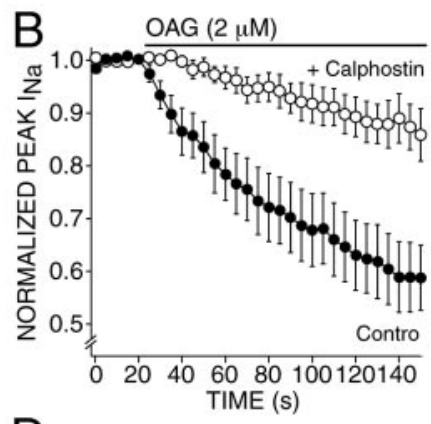

D

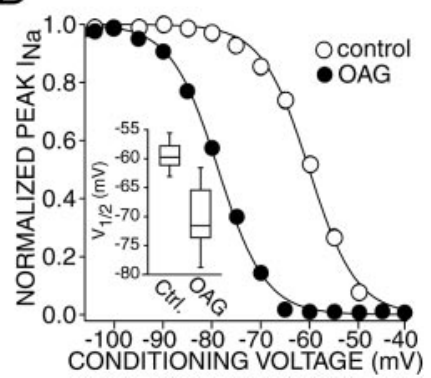

Figure 6. PKC stimulation reduces rapidly inactivating $\mathrm{Na}^{+}$current and produces a negative shift in the voltage dependence of steady-state inactivation. $A$, A representative cell showing the reduction in $\mathrm{Na}^{+}$current after a 2 min exposure to the PKC activator OAG $(2 \mu \mathrm{M})$. B, Plot of average (mean \pm SEM) normalized $\left(I / I_{\max }\right)$ peak $\mathrm{Na}^{+}$current evoked by a step from a holding potential of -70 to $-35 \mathrm{mV}$ as a function of time. OAG markedly reduced peak $\mathrm{Na}^{+}$current during a 2 min exposure (filled circles, $n=6$ ). This reduction was significantly reduced in cells dialyzed with the PKC inhibitor calphostin C $(1 \mu \mathrm{M}$, open circles, $n=6)$. $C$, A representative inactivation plot showing peak $\mathrm{Na}^{+}$current evoked by a step to $-10 \mathrm{mV}$ from a range of conditioning voltages. After a $2 \mathrm{~min}$ OAG exposure, the peak $\mathrm{Na}^{+}$current evoked from all conditioning potentials was significantly reduced. $D$, A plot of normalized $\left(I / I_{\max }\right)$ data from $C$ more clearly shows a significant negative shift in the voltage dependence of inactivation by OAG. Inset, Box plot summary of the shift in $V_{1 / 2}$ produced by OAG $(n=6)$.

has shown that deep layer PFC pyramidal neurons express primarily PLC $\beta 1$ and PLC $\beta 4$ isoforms (Day et al., 2002). Our results indicate that the effects of $5-\mathrm{HT}_{2 \mathrm{a} / \mathrm{c}}$ receptor activation on $\mathrm{Na}^{+}$ currents are mediated by this $\mathrm{G}_{\mathrm{q}}-\mathrm{PLC} \beta-\mathrm{PKC}$ pathway, as blockade of each step in the signaling cascade significantly reduced the effect of $5-\mathrm{HT}_{2 \mathrm{a} / \mathrm{c}}$ receptor stimulation on peak $\mathrm{Na}^{+}$current. Direct activation of PKC also mimicked the effects of $5-\mathrm{HT}_{2 \mathrm{a} / \mathrm{c}}$ receptor stimulation on peak $\mathrm{Na}^{+}$current, further supporting a role of the kinase in this pathway. Experiments using the $\mathrm{Ca}^{2+}$ chelator BAPTA suggest that the $5-\mathrm{HT}_{2 \mathrm{a} / \mathrm{c}}$-induced reduction in peak $\mathrm{Na}^{+}$is mediated by a member of the classical, $\mathrm{Ca}^{2+}$ sensitive PKC family. Although not tested in this study, previous work in our laboratory has demonstrated that $5-\mathrm{HT}_{2 \mathrm{a} / \mathrm{c}}$ receptor stimulation produces an $\mathrm{IP}_{3}$-mediated release of $\mathrm{Ca}^{2+}$ from intracellular stores (Day et al., 2000). Thus, it is likely that both limbs of the DAG/IP3 pathway converge on a classical isoform of PKC to bring about the modulation of $\mathrm{Na}^{+}$currents in PFC pyramidal neurons.

Activation of PKC by $5-\mathrm{HT}_{2 \mathrm{a} / \mathrm{c}}$ receptor stimulation produced two alterations in the gating of $\mathrm{Na}^{+}$channels: a reduction in the maximal $\mathrm{Na}^{+}$current when fast inactivation is removed and a negative shift in the voltage dependence of fast inactivation. Both alterations were dependent on PKC activation. A reduction in maximal $\mathrm{Na}^{+}$current amplitude is a commonly observed consequence of PKC activation, being seen not only in heterologous
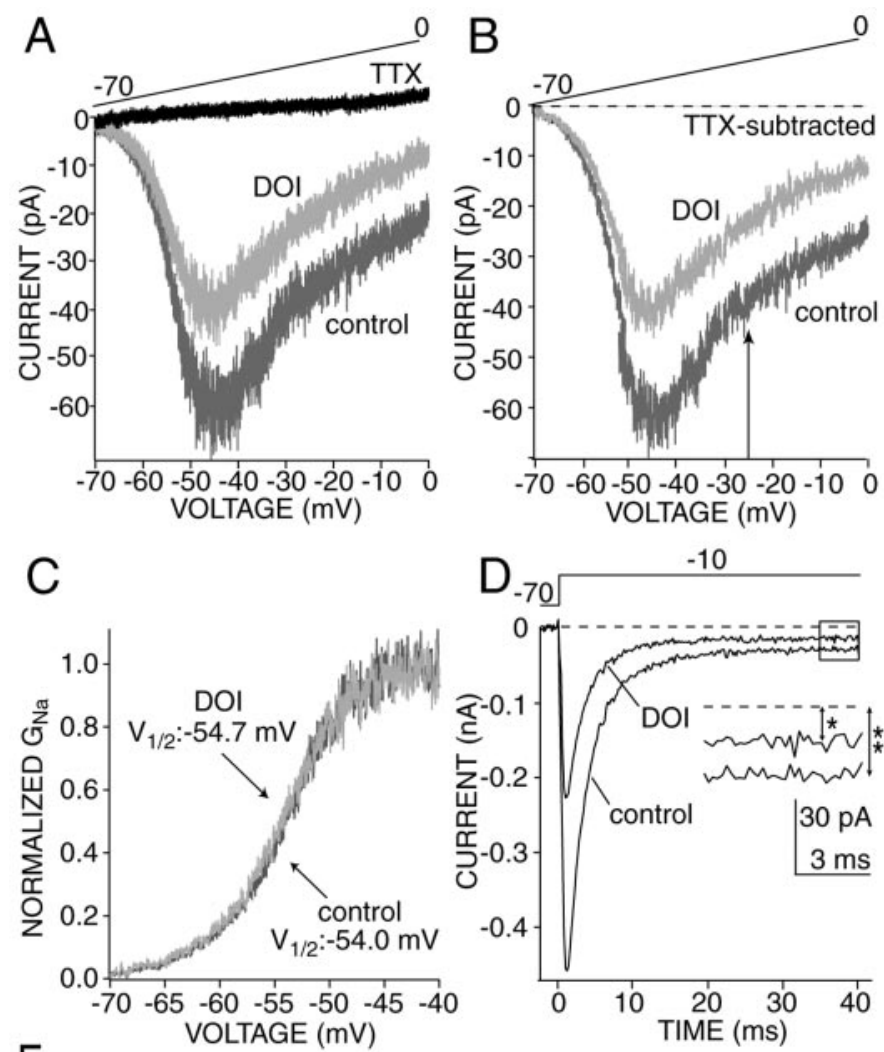

$\mathrm{E}$

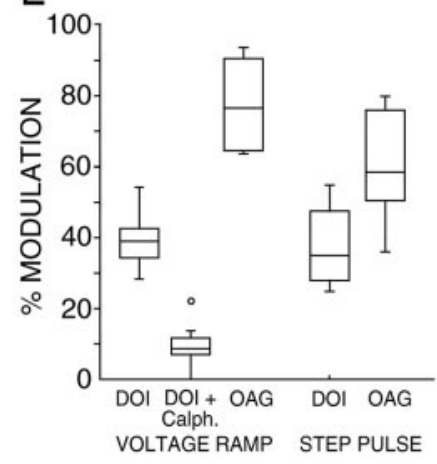

Figure 7. $5-\mathrm{HT}_{2 \mathrm{a} / \mathrm{c}}$ receptor stimulation reduces persistent $\mathrm{Na}^{+}$current via a PKC-dependent mechanism. $A$, DOI $(10 \mu \mathrm{M})$ reduced persistent $\mathrm{Na}^{+}$current evoked in $115 \mathrm{~mm}$ external $\mathrm{Na}^{+}$by a 2 sec voltage ramp from a holding potential of -70 to $0 \mathrm{mV}$. $B$, TTX subtracted currents from the cell in $A$. The persistent current amplitude was measured at $-25 \mathrm{mV}$ (arrow) to avoid contamination by window current. $C$, DOI did not alter the activation kinetics of the persistent current. $D$, DOI also reduced the amplitude of persistent $\mathrm{Na}^{+}$current measured at the end of a $40 \mathrm{msec}$ step pulse in $10 \mathrm{~mm}$ external $\mathrm{Na}^{+}$. The persistent component in the boxed area is magnified to more clearly show the reduced amplitude of DOI $\left.{ }^{*}\right)$ compared with control (**) traces. $E$, Box plot summary of the modulation of persistent $\mathrm{Na}^{+}$current by DOI measured by voltage ramps $(n=$ $10)$ or by a step pulse $(n=10)$. Dialysis with the PKC inhibitor calphostin C $(1 \mu \mathrm{M})$ significantly attenuated the DOI effect on persistent current evoked by voltage ramps $(n=7)$. The PKC activator OAG $(2 \mu \mathrm{M})$ also markedly reduced persistent $\mathrm{Na}^{+}$current measured by either step pulses $(n=5)$ or voltage ramps $(n=6)$.

expression systems but in native expression systems as well (for review, see Cantrell and Catterall, 2001). The PKC phosphorylation sites of the $\mathrm{Nav1.2} \mathrm{Na}^{+}$channel subunit responsible for this aspect of the modulation have been mapped by site directed mutagenesis (Cantrell and Catterall, 2001), and these sites are 

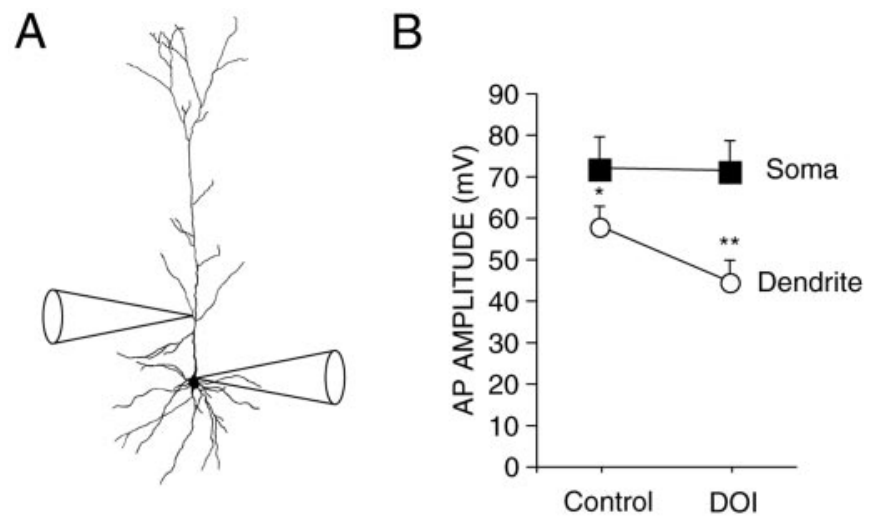

C

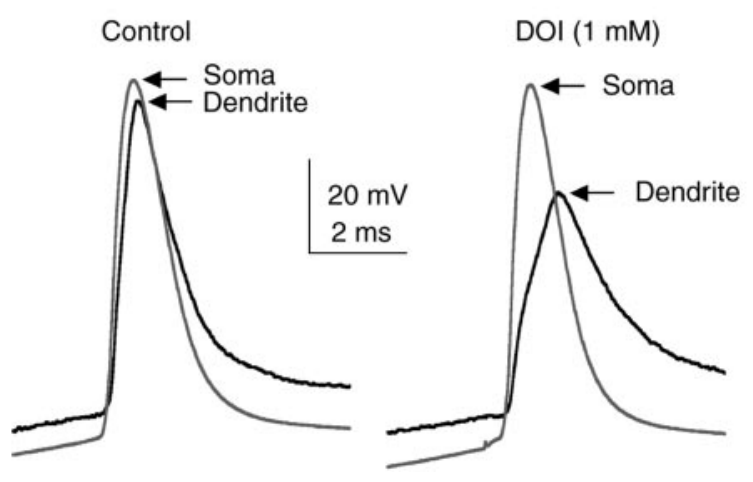

Figure 8. 5- $\mathrm{HT}_{2 \mathrm{a} / \mathrm{c}}$ receptor stimulation reduces the amplitude of backpropagating action potentials in the apical dendrites of PFC pyramidal neurons. $A$, Reconstruction of a PFC layer $\mathrm{V}$ pyramidal neuron from which simultaneous somatic and dendritic $(110 \mu \mathrm{m})$ recordings were obtained. $B$, The amplitude of dendritic action potentials was significantly smaller than somatic action potentials $\left({ }^{*} p<0.03 ; n=6\right)$. DOI $(1 \mu \mathrm{M})$ reduced the amplitude of backpropagating dendritic action potentials without affecting somatic spike amplitude $\left({ }^{* *} p<0.01 ; n=6\right)$. $C$, Example of simultaneous recordings from the cell shown in $B$. Note the reduction of dendritic action potential amplitude in DOI, which also produced a slowing of the action potential rise time in the dendrite but not in the soma.

conserved in the other $\mathrm{Na}^{+}$channel subunits prominently expressed in the brain (Nav1.1, 1.6).

A negative shift in the voltage dependence of fast inactivation is a less commonly observed consequence of PKC activation. Similar alterations in fast inactivation have been seen in heterologous systems (Dascal and Lotan, 1991; Goody and Cukierman, 1994) and sensorimotor cortex pyramidal neurons (Franceschetti et al., 2000) after nominal PKC activation. This shift in voltage dependence was not accompanied by a detectable alteration in inactivation kinetics (Numan et al., 1991). The molecular mechanisms mediating this component of the modulation are not clear. Given the apparent dependence of the modulation on cell type, its expression must turn on cell-specific proteins either in the channel complex or in the PKC signaling cascade. One possibility is that in cortical pyramidal neurons and some other cell types, PKC transactivates a tyrosine kinase, leading to phosphorylation of the $\mathrm{Na}^{+}$channel and a negative shift in the voltage dependence of fast inactivation (Hilborn et al., 1998; Tang et al., 2002). Complexities in the signaling pathway linking PKC isoforms and $\mathrm{Na}^{+}$channels may underlie other discrepancies in the experimental literature where changes in the state of previously mapped PKC phosphorylation sites have not been determined.

\section{$5-\mathrm{HT}_{2 \mathrm{a} / \mathrm{c}}$ receptor stimulation reduces persistent $\mathrm{Na}^{+}$current via a $\mathrm{G}_{\mathrm{q}}-$ PLC-PKC-dependent signaling pathway}

$5-\mathrm{HT}_{2 \mathrm{a} / \mathrm{c}}$ receptor stimulation also produced a marked reduction in the amplitude of persistent $\mathrm{Na}^{+}$currents in PFC pyramidal neurons. Given the likelihood that rapidly inactivating and persistent $\mathrm{Na}^{+}$currents arise from the same channel populations (Crill, 1996; Maurice et al., 2001) this result is not surprising. The modulation was dependent on activation of PKC, because it was blocked by the PKC inhibitor calphostin and mimicked by direct PKC stimulation. These results are consistent with previous study of another PKC-linked signaling pathway in pyramidal neurons, that of muscarinic acetylcholine receptors (Mittmann and Alzheimer, 1998). Our results do differ from those of two recent studies of hippocampal and cortical pyramidal neurons, arguing that PKC activation shifts the activation voltage dependence of persistent $\mathrm{Na}^{+}$currents toward more negative membrane potentials, resulting in enhanced excitability (Astman et al., 1998; Franceschetti et al., 2000). A PKC-induced shift in activation voltage dependence was not found in PFC pyramidal neurons, and dendritic excitability was depressed, not enhanced. Examination of PKC-mediated modulation of persistent $\mathrm{Na}^{+}$currents in striatal neurons also has failed to detect any change in activation properties (our unpublished observations). The origins of the discrepancy are unclear at present. As mentioned above, it may be that cell-specific variation in signaling elements downstream of PKC or in channel composition may contribute to different patterns of modulation. It is of note that recent work by Taddese and Bean (2002) in tuberomammillary neurons suggests a close linkage between the voltage dependence of persistent $\mathrm{Na}^{+}$current activation and the voltage dependence of transient $\mathrm{Na}^{+}$current inactivation. Their model makes two predictions about the consequences of the PKC-mediated modulation rapidly inactivating $\mathrm{Na}^{+}$current. First, because the persistent current is essentially a "window" current, the shift in the voltage dependence of fast inactivation should result in a greater reduction of persistent $\mathrm{Na}^{+}$ current than of transient current at relatively hyperpolarized holding potentials. In fact this was the case in our hands; equimolar DOI reduced persistent current by $\sim 40 \%$ on average but only reduced peak rapidly inactivating current by $\sim 25 \%(p<0.01$; Kruskal-Wallis). The second prediction is that the shift in fast inactivation should have been accompanied by a hyperpolarizing shift in persistent current activation. As noted above, this did not occur in PFC pyramidal neurons but could account for the change seen in other studies.

\section{Functional significance}

Within the past decade, a considerable body of evidence has accumulated in support of the view that dendrites contain a variety of voltage-gated channels (Magee, 1999; Stuart et al., 1999). One of the main functions of these channels is to govern the spread of action potentials into the dendritic tree. Our results show that $5-\mathrm{HT}_{2}$ receptor agonists can exert a strong influence over action potentials backpropagating into the apical dendrite of PFC pyramidal cells. This regulation of dendritic channels by $5-\mathrm{HT}$ is consistent with the high density of $5-\mathrm{HT}_{2 \mathrm{a}}$ and $5-\mathrm{HT}_{2 \mathrm{c}}$ receptors along the apical dendrites of these neurons (Jakab and Goldman-Rakic, 1998; Cornea-Herbert et al., 1999; Clemett et al., 2000). The most parsimonious explanation for the reduction in dendritic spike amplitude and rate of rise $(\Delta V / \Delta t)$ is a reduction in $\mathrm{Na}^{+}$channel availability, just as shown by our voltageclamp analysis. This does not exclude $5-\mathrm{HT}_{2}$ receptor-PKC mod- 
ulation of other channels capable of influencing backpropagation (e.g., Kv4 $\mathrm{K}^{+}$channels, Hoffman and Johnston, 1998). Other receptor subtypes activated by 5 -HT also could engage collateral mechanisms to support this modulation. For example, $5-\mathrm{HT}_{1 \mathrm{~A}}$ receptors reduce spike height in CA1 hippocampal pyramidal neurons by hyperpolarizing the dendrite (Sandler and Ross, 1999). However, the potential importance of cellular specificity in these regulatory mechanisms cannot be underestimated. In hippocampal pyramidal neurons, for instance, $\mathrm{PKC}$ activators reduce slow inactivation of dendritic $\mathrm{Na}^{+}$channels and diminish the attenuation in dendritic spike amplitude seen with repetitive activation (Colbert and Johnston, 1998). Although we did not look at activity-dependent attenuation of dendritic spikes, PKC (and $5-\mathrm{HT}_{2}$ receptor) activation enhances (not reduces) the development of $\mathrm{Na}^{+}$channel slow inactivation in PFC pyramidal neurons (our unpublished observations). As noted above, this variation in the response to PKC activation may turn on nuances in downstream signaling cascades that lead to unexpected final effectors of the observed modulation. Only by working backwards from principles deduced in reduced preparations are we likely to unravel these events.

Sorting these principles out is important because of the potentially broad impact of dendritic excitability. Backpropagating spikes can elevate dendritic $\mathrm{Ca}^{2+}$ by opening voltage-gated $\mathrm{Ca}^{2+}$ channels and by relieving the $\mathrm{Mg}^{2+}$ block of NMDA receptors. Both of these actions may influence the induction of synaptic plasticity (Magee and Johnston, 1997). By reducing spike backpropagation, $5-\mathrm{HT}_{2}$ receptors may block the induction of synaptic plasticity in apical PFC dendrites. The block of $\mathrm{Ca}^{2+}$-dependent plasticity in PFC pyramidal neurons should be strengthened by $5-\mathrm{HT}_{2}$ receptor inhibition of L-type $\mathrm{Ca}^{2+}$ channels (Day, 2002). The dampening of excitability and plasticity should also influence orthodromically initiated $\mathrm{Na}^{+}$and $\mathrm{Ca}^{2+}$ spikes in pyramidal neuron dendrites (Stuart et al., 1997; Golding and Spruston, 1998; Golding et al., 1999; Larkum et al., 1999). 5-HT also may reduce synaptic integration in PFC pyramidal neurons specifically through its effects on persistent $\mathrm{Na}^{+}$current. Persistent $\mathrm{Na}^{+}$ current arising in the soma, proximal dendrites, or axon has been shown to enhance EPSPs evoked at depolarized potentials in cortical pyramidal neurons (Stuart and Sakmann, 1995; Gonzalez-Burgos and Barrionuevo, 2001). Although 5- $\mathrm{HT}_{2}$ receptor activation of PKC is likely to bring about a coordinated modulation of several conductances, the reduction of persistent $\mathrm{Na}^{+}$currents in and of itself should serve limit EPSP enhancement at depolarized potentials (Aghajanian and Marek, 1997).

\section{REFERENCES}

Aghajanian GK, Marek GJ (1997) Serotonin induces excitatory postsynaptic potentials in apical dendrites of neocortical pyramidal cells. Neuropharmacology 36:589-599.

Akhter SA, Luttrell LM, Rockman HA, Iaccarino G, Lefkowitz RJ, Koch WJ (1998) Targeting the receptor- $\mathrm{G}_{\mathrm{q}}$ interface to inhibit in vivo pressure overload myocardial hypertrophy. Science 280:574-577.

Araneda R, Andrade R (1991) 5-Hydroxytryptamine 2 and 5 -hydroxytryptamine $1 \mathrm{~A}$ receptors mediate opposing responses on membrane excitability in rat association cortex. Neuroscience 40:399-412.

Ashby Jr CR, Edwards E, Harkins K, Wang RY (1989) Effects of (+/ $-)$-DOI on medial prefrontal cortical cells: a microiontophoretic study. Brain Res 498:393-396.

Astman N, Gutnick MJ, Fleidervish IA (1998) Activation of protein kinase $\mathrm{C}$ increases neuronal excitability by regulating persistent $\mathrm{Na}^{+}$ current in mouse neocortical slices. J Neurophysiol 80:1547-1551.

Bristow LJ, Kramer MS, Kulagowski J, Patel S, Ragan CI, Seabrook GR (1997) Schizophrenia and L-745, 870, a novel dopamine D4 receptor antagonist. Trends Pharmacol Sci 18:186-188.
Cantrell AR, Catterall WA (2001) Neuromodulation of $\mathrm{Na}^{+}$channels: an unexpected form of cellular plasticity. Nat Neurosci 2:397-407.

Clemett DA, Punhani T, Duxon MS, Blackburn TP, Fone KC (2000) Immunohistochemical localisation of the $5-\mathrm{HT}_{2 \mathrm{C}}$ receptor protein in the rat CNS. Neuropharmacology 39:123-132.

Colbert CM, Johnston D (1998) Protein kinase C activation decreases activity-dependent attenuation of dendritic $\mathrm{Na}^{+}$current in hippocampal CA1 pyramidal neurons. J Neurophysiol 79:491-495.

Cornea-Herbert V, Riad M, Wu C, Singh SK, Descarries L (1999) Cellular and subcellular distribution of the serotonin $5-\mathrm{HT}_{2 \mathrm{~A}}$ receptor in the central nervous system of adult rat. J Comp Neurol 409:187-209.

Crill WE (1996) Persistant sodium current in mammalian central neurons. Annu Rev Physiol 58:349-362.

Dascal N, Lotan I (1991) Activation of protein kinase C alters voltage dependence of a Na ${ }^{+}$channel. Neuron 6:165-175.

Day M, Hernandez-Lopez S, Surmeier DJ (2000) The effects of serotonin $5-\mathrm{HT}_{2 \mathrm{a}}$ agonists on high voltage activated calcium currents in prefrontal pyramidal neurons. Soc Neuroscience Abstr 26:534.10.

Day M, Olson PA, Platzer J, Striessnig J, Surmeier DJ (2002) Stimulation of serotonin $5-\mathrm{HT}_{2}$ receptors in prefrontal pyramidal neurons inhibits $\mathrm{Ca}_{\mathrm{v}} 1.2 \mathrm{~L}$-type $\mathrm{Ca}^{2+}$ channel currents via a PLC $\beta / \mathrm{IP} 3 / \mathrm{cal}$ cineurin signaling cascade. J Neurophysiol, in press.

Feng J, Cai X, Z hao J, Yan Z (2001) Serotonin receptors modulate $\mathrm{GABA}_{\mathrm{A}}$ receptor channels through activation of anchored protein kinase $C$ in prefrontal cortical neurons. J Neurosci 21:6502-6511.

Franceschetti S, Taverna S, Sancini G, Panzica F, Lombardi R, Avanzini G (2000) Protein kinase C-dependent modulation of $\mathrm{Na}^{+}$currents increases the excitability of rat neocortical pyramidal neurones. J Physiol (Lond) 528:291-304.

Franklin KBJ, Paxinos G (1997) The mouse brain in stereotaxic coordinates. New York: Academic.

Glennon RA, Dukat M (1995) Serotonin receptor subtypes. In: Psychopharmacology: the fourth generation of progress (Bloom FE, Kupfer DJ, eds), pp 415-429. New York: Raven.

Golding NL, Spruston N (1998) Dendritic sodium spikes are variable triggers of axonal action potentials in hippocampal CA1 pyramidal neurons. Neuron 21:1189-1200.

Golding NL, Jung HY, Mickus T, Spruston N (1999) Dendritic calcium spike initiation and repolarization are controlled by distinct potassium channel subtypes in CA1 pyramidal neurons. J Neurosci 19:8789-8798.

Gonzalez-Burgos GR, Barrionuevo G (2001) Voltage-gated sodium channels shape subthreshold EPSPs in layer 5 pyramidal neurons from rat prefrontal cortex. J Neurophysiol 86:1671-1684.

Goody CMG, Cukierman S (1994) Multiple effects of protein kinase C activators on $\mathrm{Na}^{+}$currents in mouse neuroblastoma cells. J Membr Biol 140:101-110.

Hilborn MD, Vaillancourt RR, Rane SG (1998) Growth factor receptor tyrosine kinases acutely regulate neuronal sodium channels through the Src signaling pathway. J Neurosci 18:590-600.

Hille B (1992) Ionic channels of excitable membranes, Ed 2. Sunderland, MA: Sinauer.

Hoffman DA, Johnston D (1998) Downregulation of transient K+ channels in dendrites of hippocampal CA1 pyramidal neurons by activation of PKA and PKC. J Neurosci 18:3521-3528.

Jakab RL, Goldman-Rakic PS (1998) 5-Hydroxytryptamine serotonin $^{\text {s }}$ receptors in the primate cerebral cortex: possible site of action of hallucinogenic and antipsychotic drugs in pyramidal cell apical dendrites. Proc Natl Acad Sci USA 95:735-740.

Larkum ME, Zhu JJ, Sakmann B (1999) A new cellular mechanism for coupling inputs arriving at different cortical layers. Nature 398:338-341.

Lipowsky R, Gillessen T, Alzheimer C (1996) Dendritic $\mathrm{Na}^{+}$channels amplify EPSPs in hippocampal CA1 pyramidal cells. J Neurophysiol 76:2181-2191.

Liu WS, Heckman CA (1998) The sevenfold way of PKC regulation. Cell Signal 10:529-542.

Magee JC (1999) Voltage-gated ion channels in dendrites. In: Dendrites (Stuart G, Spruston N, Hausser M, eds), pp 139-160. New York: Oxford UP

Magee JC, Johnston D (1997) A synaptically controlled associative signal for Hebbian plasticity in hippocampal neurons. Science 275:209-213.

Mantz J, Godbout R, Tassin J-P, Glowinski J, Thierry A-M (1990) Inhibition of spontaneous and evoked unit activity in the rat medial prefrontal cortex by mesencephalic raphe nuclei. Brain Res 524:22-30.

Maurice N, Tkatch T, Meisler M, Sprunger LK, Surmeier DJ (2001) $\mathrm{D}_{1} / \mathrm{D}_{5}$ dopamine receptor activation differentially modulates rapidly inactivating and persistent sodium currents in prefrontal cortex pyramidal neurons. J Neurosci 21:2268-2277.

Meltzer HY (1999) The role of serotonin in antipsychotic drug action. Neuropsychopharmacology 21:106S-115S.

Mittmann T, Alzheimer C (1998) Muscarinic inhibition of persistent $\mathrm{Na}^{+}$current in rat neocortical pyramidal neurons. J Neurophysiol 79:1579-1582.

Numan R, Catterall WA, Scheuer T (1991) Functional modulation of 
brain sodium channels by protein kinase $\mathrm{C}$ phosphorylation. Science 254:115-118.

Sanders-Bush E, Canton H (1995) Serotonin receptors: signal transduction pathways. In: Psychopharmacology: The fourth generation of progress (Bloom FE, Kupfer DJ, eds), pp 431-441. New York: Raven.

Sandler VM, Ross WN (1999) Serotonin modulates spike backpropagation and associated $\left[\mathrm{Ca}^{2+}\right]_{\mathrm{i}}$ changes in the apical dendrites of hippocampal CA1 pyramidal neurons. J Neurophysiol 81:216-224.

Schwindt PC, Crill WE (1995) Amplification of synaptic current by persistent sodium conductance in apical dendrite of neocortical neurons. J Neurophysiol 74:2220-2224.

Seeman P (1992) Dopamine receptor sequences: therapeutic levels of neuroleptics occupy $\mathrm{D}_{2}$ receptors, clozapine occupies $\mathrm{D}_{4}$. Neuropsychopharmacology 7:261-284.

Stuart G, Sakmann B (1994) Active propagation of somatic action potentials into neocortical pyramidal cell dendrites. Nature 367:69-72.

Stuart G, Sakmann B (1995) Amplification of EPSPs by axosomatic sodium channels in neocortical pyramidal neurons. Neuron 15:1065-1076.
Stuart G, Schiller J, Sakmann B (1997) Action potential initiation and propagation in rat neocortical pyramidal neurons. J Physiol (Lond) 505:617-632.

Stuart G, Spruston N, Hausser M (1999) Dendrites. New York: Oxford University Press.

Taddese A, Bean BP (2002) Subthreshold sodium current from rapidly inactivating sodium channels drives spontaneous firing of tuberomammillary neurons. Neuron 33:587-600.

Tang X, Batty IH, Downes CP (2002) Muscarinic receptors mediate phospholipase $\mathrm{C}$-dependent activation of protein kinase $\mathrm{B}$ via $\mathrm{Ca}^{2+}$, ErbB3, and phosphoinositide 3-kinase in 1321N1 astrocytoma cells. J Biol Chem 277:338-344.

Vysokanov A, Flores-Hernandez J, Surmeier DJ (1998) mRNAs for clozapine sensitive receptors co-localize in rat prefrontal cortex neurons. Neurosci Lett 258:179-182.

Weinberger DR (1988) Schizophrenia and the frontal lobe. Trends Neurosci 11:367-370. 